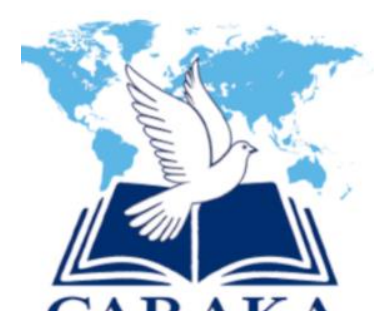

\begin{tabular}{|l|l|l|}
\hline Diserahkan: 9 Juni 2021 & Diterima: 12 Agustus 2021 & Diterbitkan: 10 Oktober 2021 \\
\hline
\end{tabular}

\title{
Khotbah Yang Efektif Bagi Generasi Milenial Di Era Post Modern
}

\author{
Jefri Hina Remi Katu \\ Sekolah Tinggi Teologi Satyabhakti \\ jefrihinna@gmail.com
}

\begin{abstract}
Preaching to the millennial generation has its own challenges where this generation often known as instant generation and fast-paced that is influenced by postmodern culture. This generation also does not want to listen a lecturer or sermon that seems to long-winded. The literature analysis on this article can provide insight regarding the characteristics of the millennial generation as the audience of the message that being preached. This article describe the characteristics of the the millennial generation that become a reference in an effective preaching. An effective preaching to the millennial generation is throught the strategies of the preachers that the duration of his/her sermon is not too long, concise, and clear. And then, the selection of slangs diction of the millennial generation are required.
\end{abstract}

Keywords: Millennial Generation; postmodernism; Culture; Preaching

\begin{abstract}
Abstrak
Berkhotbah kepada generasi milenial memiliki tantangan tersendiri di mana generasi ini kerap dikenal sebagai generasi yang instan yang serba cepat yang dipengaruhi oleh budaya postmodern dan tidak mau mendengarkan suatu ceramah atau khotbah yang terkesan berteletele. Pendekatan kajian pustaka dalam artikel ini dapat memberikan wawasan terkait karakteristik generasi milenial sebagai pendengar berita firman yang dikhotbahkan. Artikel ini memaparkan karakteristik generasi milenial yang menjadi acuan dalam strategi penyampaian khotbah yang efektif. Sebuah khotbah yang efektif kepada generasi milenial adalah melalui strategi-strategi dari para pengkhotbah yang durasi khotbahnya tidak terlalu lama dan berteletele, singkat, dan jelas. Kemudian, pemilihan bahasa-bahasa 'gaul' generasi milenial disyaratkan.
\end{abstract}

Kata kunci: Generasi Milenial; Postmodernisme; Budaya; Khotbah. 


\section{PENDAHULUAN}

Khotbah merupakan salah satu bagian terpenting dalam ibadah di gereja. Pada masa reformasi, Martin Luther, sebagai salah satu tokoh reformasi Gereja pada abad pertengahan, menekankan teologi "Firman Allah" sebagai "starting point" dan otoritas final dari teologinya. Hal ini diungkapkan oleh Gonzales bahwa "As is commonly known, Luther sought to make the Word of God the starting point and the final authority for his theology"1 ungkapan ini menampilkan bahwa Firman Allah merupakan wujud penyingkapan diri Allah sendiri yang berinkarnasi dalam Kristus.

Dalam Injil Yohanes 1, Yohanes menunjukkan bahwa Yesus merupakan inkarnasi dari Sang Firman tersebut yang berperan aktif dalam penciptaan. Kehadiran Yesus dalam inkarnasinya sebagai manusia sedang menyingkapkan Allah yang terus bertindak secara aktif dalam karya keselamatan yang dimulai sejak awal penciptaan. Itu sebabnya, bagi Luther, "Firman Allah" adalah tidak lain dari Allah sendiri yang telah berinkarnasi melalui pribadi Yesus yang diam bersama dengan ciptaan-Nya. Alkitab merupakan Firman Allah yang tertulis karena Alkitab berbicara mengenai Yesus sang Firman yang berinkarnasi menjadi manusia untuk karya keselamatan bagi semua ciptaan-Nya. Luther menegaskan otoritas akhir dari Alkitab atas gereja dan bukan gereja yang menjadi otoritas tertinggi atas Alkitab. ${ }^{2}$

Gonzales juga menampilkan "The Bible is the Word of God because in it Jesus, the Word incarnate, comes to us. Any who read the Bible and somehow do not find Jesus in it, have not encountered the Word of God." Kekristenan meyakini bahwa Alkitab merupakan penyingkapan diri Allah dalam sejarah di mana umat Allah yang disebutkan dalam tulisan Alkitab mengalami perjumpaan dengan Allah perlu untuk dijelaskan melalui khotbah. Khotbah memiliki peran penting dalam pemberitaan Firman Allah bukan hanya sebagai kesempatan mengajarkan makna teks-teks Alkitab kepada umat Allah, namun juga memberitakan siapa Allah kepada gereja Tuhan. Dalam pemberitaan Firman melalui khotbah para pendengar diajak untuk berada dalam sebuah dimensi pengalaman dengan Allah melalui berita firman yang disampaikan oleh pengkhotbah.

Alkitab penting untuk dikhotbahkan kepada generasi digital, dalam hal ini generasi milenial, agar membawa mereka pada pengalaman kuasa adikodrati firman yang disampaikan. Berkhotbah bukanlah tugas yang mudah karena tugas ini menuntut para pengkhotbah untuk belajar bagaimana memahami pendengarnya. Sebagaimana Gonzalez ungkapkan mengenai teologi "Firman Allah" Luther bahwa, "the Bible has authority over the church, pope, and

\footnotetext{
${ }^{1}$ Justo L. Gonzalez, The Story of Christianity: The Reformation to the Present Day (New York, NY: Harper Collins Publishers, 2010), 47.

${ }^{2}$ Ibid., 48.

${ }^{3}$ Ibid.
} 
tradition." Salah satu tantangan para pengkhotbah adalah bagaimana menyampaikan khotbah yang efektif kepada generasi milenial.

Gereja secara umum saat ini sedang berada dalam era milenium dan sedang menyaksikan era perubahan budaya yang begitu cepat, seperti perubahan persepsi dan asumsi. Gibson mengutarakan bahwa, "Preaching has had to change. For evangelicals, hopefully, content of the sermon has not changed. However, preachers are confronted with how the engage with the challenges of culture's shift." Lebih lanjut Gibson menyatakan bahwa, "The present era has been a sea change of ideas, morals, and practice. The sea change can be seen in congregations in which we preach. The composition of our congregations has altered the way we understand them and preach to them." Perubahan persepsi dan budaya pemikiran tidak dapat terhindarkan. Oleh sebab itu, pengkhotbah dituntut untuk menyadari perubahanperubahan budaya pendengarnya sehingga dapat menyampaikan khotbah yang efektif dan relevan bagi setiap pendengarnya.

Perubahan yang terjadi dalam budaya pemikiran dan persepsi saat ini menuntut para pengkhotbah mengubah diksi dari isi dan gaya penyampaian khotbah. Diksi berarti pemilihan kata yang tepat yang sesuai dengan konteks pendengar seperti pemilihan kata yang cocok dengan konteks generasi milenial. Diksi yang digunakan bertujuan agar ide atau gagasan yang disampaikan dalam cerita dapat dipahami dengan jelas oleh pendengar. Berkaitan dengan diksi yang dipakai dalam khotbah kepada generasi milenial tersebut tidak sedang mempengaruhi isi pesan utama khotbah, namun merupakan usaha untuk menjadikan pesan Firman kepada generasi milenial dapat tersampaikan dengan jelas dan dapat dipahami oleh mereka.

Terkait perubahan budaya saat ini, para pengkhotbah mendapat tantangan untuk bagaimana menyampaikan khotbah kepada budaya generasi milenial pada era postmodern ini. Generasi ini memiliki keunikan tersendiri dalam menanggapi khotbah yang disampaikan oleh seorang pengkhotbah. Jika pengkhotbah memiliki gaya modern atau gaya pre modern dalam menyampaikan khotbah, maka pengkhotbah akan mengalami kesulitan dalam menyeberangkan pesan Firman kepada pendengarnya. Diksi dari isi khotbah harus relevan dengan budaya pendengar milenial. Oleh karena itu, artikel bertujuan untuk melakukan suatu analisa terhadap karkateristik generasi milenial agar memberikan sumbangsih yang signifikan kepada para pengkhotbah dalam mempersiapkan diksi dari setiap isi khotbah yang akan diberitakan melalui mimbar-mimbar gereja serta juga berpengaruh kepada gaya

${ }^{4}$ Ibid.

${ }^{5}$ Scott M. Gibson, "Introduction," in Preaching to a Shifting Culture: 12 Perspective on Communicating That Connects, ed. Scott M. Gibson (Grand Rapids, MI, 2004), 12.

${ }^{6}$ Ibid, 13. 
penyampaiannya. Selain itu, artikel ini bisa menjawab pergumulan para pengkhotbah ketika hendak mempersiapkan khotbah yang efektif kepada pendengar milenial dengan berusaha mempelajari karakteristik pendengar milenial.

\section{METODE PENELITIAN}

Metode penelitian yang diterapkan dalam penulisan ini adalah pendekatan kajian pustaka. Dalam rangka menanggapi pengaruh budaya postmodernisme dalam gereja, maka penulis akan berdiskusi dengan sumber-sumber terkait prinsip fundamental dalam penyampaian khotbah dan memperbincangkannya dengan pandangan budaya postmodern. Artikel ini akan membahas mengenai alasan pentingnya khotbah mulai dari sejarah perkembangan gereja hingga berkhotbah kepada generasi milenial menjadi tantangan yang unik.

\section{HASIL DAN PEMBAHASAN}

\section{Pentingnya Berkhotbah}

Penyampaian khotbah menjadi bagian penting dalam penguraian yang jelas mengenai pengungkapan siapa Allah. ${ }^{7}$ Dalam tradisi Yahudi, pertemuan ibadah di Sinagoge meliputi pembacaan dan penjelasan salah satu Kitab Suci oleh pemimpin agama kepada umat yang hadir. Praktik tersebut menjadi bagian penting dalam setiap pertemuan ibadah dan diwarisi oleh gereja sejak perkembangan awal hingga saat ini. ${ }^{8}$ Hal yang perlu menjadi catatan penting bagi para pengkhotbah adalah bahwa penyampaian khotbah memiliki kekhasan dan tantangan tersendiri dalam setiap perkembangan zaman yang sesuai dengan konteks tertentu.

Buttrick $^{9}$ menampil lima catatan teologis mengenai alasan pentingnya berkhotbah. Pertama, berkhotbah merupakan perintah Yesus untuk melanjutkan pelayanan berkhotbah yang dilakukan oleh Yesus sebelum Ia naik ke Surga. Buttrick mengatakan, "We continue the preaching of Jesus Christ as witnesses to the resurrection."10 Jadi, referensi dari berita khotbah adalah mengenai kesaksian Alkitab atas mengenai sejarah karya penebusan Allah, inkarnasi, pelayanan, kematian, serta kebangkitan Kristus. Hal inilah yang menjadi dasar pertama alasan mengapa berkhotbah adalah sesuatu yang penting.

${ }^{7}$ Jerry Vines dan Jim Shaddix, Homeletika: Kuasa Dalam Berkhotbah (Malang, IDN: Gandum Mas, 1999), 23.

${ }^{8}$ Ibid., 24.

${ }^{9}$ David G. Buttrick, Homeiletic: Moves and Structures (Philadelphia: Fortress Press, 1987), Ch. 26, ebook.

${ }^{10}$ Ibid., ch. 26. 
Kedua, berkhotbah merupakan anugerah Allah. Buttrick mengatakan "In our preaching, Christ continues to speak to the church, and through the church to the world."11 Melalui pemberdayaan kuasa Roh Kudus, seorang pengkhotbah diberdayakan untuk menyampaikan khotbah kepada gereja dan dunia agar melalui berita firman yang disampaikan melalui khotbah dapat membawa transformasi hidup kepada pendengar. Green menyampaikan bahwa berkhotbah sebagai sebuah "Theotic Encounter" 12 atau sebuah perjumpaan dengan Allah. Sebagai sebuah perjumpaan dengan Allah, tentu peranan berkhotbah dalam hal ini adalah untuk mengumpulkan umat untuk mendengarkan kesaksian tentang Allah yang menyelamatkan manusia. Oleh karena itu, bagi Green, berkhotbah merupakan peristiwa Roh Kudus (sebagai salah satu dari pribadi Tritunggal) yang memampukan seorang pengkhotbah untuk menyampaikan pesan firman Allah. Roh Kudus juga menolong umat yang mendengar untuk mengalami perjumpaan dengan Allah yang menyelamatkan umat Allah yang tercatat dalam Alkitab sebagai pengamalan mereka juga pada saat mendengarkan firman. ${ }^{13}$ Karena itu Buttrick mengatakan "By the Spirit, Christ speaks through us, a broken, risen community." 14 Ungkapan Buttrick menunjukkan bahwa seorang pengkhotbah tidak layak menjadi alat Allah untuk menyampaikan berita Firman, namun hal tersebut merupakan misteri dari anugerah Allah melalui pemberdayaan Roh Kudus kepada pengkhotbah.

Alasan ketiga pentingnya berkhotbah adalah rekonsiliasi Allah dengan manusia dan seluruh ciptaan-Nya. Dalam Yohanes 3:16, Allah sangat mengasihi dunia sehingga Allah menyerahkan Anak-Nya yang tunggal sehingga melaluinya seluruh ciptaan diselamatkan. Buttrik mengatakan, "The purpose of preaching, broadly considered, is nothing less than the saving purpose of God."15 Tujuan dari khotbah Kristen adalah untuk membawa berita pembebasan kepada manusia serta kepada seluruh ciptaan. Berita pembebasan yang disampaikan dalam khotbah merupakan berita karya penebusan Allah sebagai bagian tindakan pendamaian Allah dengan seluruh ciptaan agar diselamatkan.

Alasan keempat pentingnya berkhotbah adalah membangkitkan tanggapan para pendengar untuk bertobat dari perbuatan dosa dan beriman ${ }^{16}$ kepada Kristus. Muatan khotbah Kristen di satu sisi berisi tentang ajakan untuk bertobat dan di lain sisi berisi tentang dorongan kepada pendengar agar tidak kehilangan iman saat berada dalam situasi kehidupan yang sulit yang dapat menyebabkan umat Tuhan mengalami krisis iman. Buttrick menjelaskan bahwa

\footnotetext{
${ }^{11}$ Ibid., ch. 26.

${ }^{12}$ Chris E. W. Green, "Transfiguring Preaching: Salvation, Mediation, and Proclamation," in Toward a Pentecostal Theology of Preaching, ed. Lee Roy Martin (Cleveland, TN: CPT Press, 2015), ch. 3.

${ }^{13}$ Ibid., ch. 3.

${ }^{14}$ Buttrick, Homeiletic: Moves and Structures, 26.

15 Ibid.

${ }^{16}$ Ibid.
} 
"faith is best understood as entrance into a new order of life and a concomitant turning from an old order (repentance) through Jesus Christ." 17 Ajakan dalam berkhotbah untuk memiliki iman dan bertobat dari dosa merupakan dua hal yang muncul bersamaan dalam khotbah.

Alasan kelima, khotbah adalah "Firman Allah" yang di dalamnya pengkhotbah turut berpartisipasi dalam tujuan Allah yang diinisiasi oleh Kristus melalui pemberdayaan Roh Kudus. ${ }^{18}$ Khotbah merupakan pesan Firman Allah mengenai siapa Allah kepada umat manusia. Karena itu, khotbah bukanlah promosi manusia atau ajang pertunjukan kemampuan pengkhotbah, melainkan ajang untuk menjelaskan Firman Allah agar umat dapat memahami maksud dan rencana Allah. Salah satu bagian penting dalam penyampaian Firman Allah adalah kemampuan untuk mengeksegesis teks serta memahami ilmu homiletik. Buttrick mengatakan bahwa, "Preaching must be described as a human activity that draws on human understanding and employs human homiletic skills that can be learned."19 Sekalipun berkhotbah adalah pemberitaan Firman Allah, namun seorang pengkhotbah perlu memperhatikan bagaimana Firman Allah dapat dipahami dan diterima oleh pendengarnya.

Tennent mengungkapkan dengan tegas terkait peran aktif dari para pengkhotbah dalam memahami prinsip yang fundamental dari isi pesan Firman yang dikhotbahkan. Tennent mengatakan bahwa,

One of the fundamental principles of preaching is that it does not occur in a vacuum. Indeed, by definition, authentic preaching is a contextual event, which must always bear marks of universality and particularity. On the one hand, preacher is one who is bearer of the universal, unchanging message of the gospel. On the other hand, that gospel must be delivered in every particular, local context. ${ }^{20}$

Penyampaian khotbah menuntut para pengkhotbah untuk menyampaikan isi berita Firman yang sesuai dengan konteks budaya tertentu agar dapat diterima dan dipahami secara jelas oleh para pendengar. Seorang pengkhotbah tidak boleh mengabaikan konteks lokal dari para pendengar serta universalitas dari pesan Firman yang dikhotbahkan. Tennent menambahkan bahwa,

To neglect the local context is to forfeit one of the great channels through which the Holy Spirit ministers grace, comfort, teaching, and guidance to His people today. To neglect the universality of the gospel is to forget that we are not the source of the message, but we are seeking to deliver faithfully the gospel that we received. ${ }^{21}$

\footnotetext{
17 Ibid.

${ }^{18}$ Ibid.

${ }^{19}$ Ibid.

20 Timothy C. Tennent, "Evangelical Preaching in the Global Context," in Preaching to a Shifting
}

Culture: 12 Perspective on Communicating That Connects, ed. Scott M. Gibson (Grand Rapids, MI, 2004$), 199$. ${ }^{21}$ Ibid., 200. 
Tennent menunjukkan dua prinsip yang fundamental kepada para pengkhotbah dalam penyampaian berita Firman. Dua prinsip yang tidak boleh diabaikan oleh para pengkhotbah adalah konteks tertentu dari pendengar dan sifat universal dari Firman yang disampaikan.

Sifat universal dari Firman yang disampaikan yang tidak boleh diabaikan. Hal ini dapat membantu pengkhotbah untuk memahami bahwa Firman Tuhan merupakan pesan yang diberikan kepada orang-orang pada zaman kuno dan masih relevan bagi pendengar pada masa kini. Karena itu, pengkhotbah perlu melakukan suatu analisa terhadap konteks sejarah serta melakukan eksegesis terhadap teks Alkitab untuk bisa disampaikan kepada pendengarnya. Tisdale mengungkapkan dengan jelas terkait khotbah yang kontekstual. Ia mengatakan:

Our quest, then is for preaching that is more intentionally contextual in nature - that is, preaching which not only gives serious attention to the interpretation of biblical texts, but which give equally serious attention to the interpretation of congregations and their sociocultural context; preaching which not only aims toward greater "faithfulness" to the gospel of Jesus Christ, but which also aims toward greater "fittingness" (in content, form and style) for a particular congregation gathering of hearers. ${ }^{22}$

Komentar Tisdale di atas mengajak para pengkhotbah untuk tidak hanya berusaha secara setia melakukan analisis terhadap teks-teks Alkitab, namun juga dituntut kesetiaannya untuk melakukan eksegesis terhadap latar belakang konteks pendengar masa kini yang mana berita Firman hendak disampaikan. Tugas untuk melakukan eksegesis terhadap teks Alkitab dan eksegesis terhadap pendengar merupakan dua tugas yang tidak boleh diabaikan karena kedua tugas tersebut akan mempengaruhi isi khotbah yang memiliki muatan teologis.

\section{Pandangan Dunia Budaya Postmodern}

Era modern menjadikan manusia sebagai pusat dari segala realitas yang ada. ${ }^{23}$ Ciri khas utama era modern adalah penekanan pada rasio manusia sebagai pusat perkembangan peradaban manusia. Rasio manusia menjadi tolak ukur dari keyakinan akan suatu kebenaran yang absolut. Jika keyakinan tidak dapat diterima secara akal atau dengan kata lain tidak dapat dibuktikan secara ilmu pengetahuan, maka hal tersebut tidak dapat diterima sebagai kebenaran. Itulah sebabnya, era modern kerap juga disebut sebagai era anti traditional. ${ }^{24}$ Bagi modernist, suatu tradisi dapat ditolak jika tradisi tersebut tidak rasional. Itulah sebabnya Era modern lahir sebagai era yang mengagungkan akal manusia dan menjadikan akal manusia sebagai penentu dari kebenaran dan mengabaikan aspek intuisi atau perasaan manusia. Karena itu, dalam era modern, kebenaran dapat diterima selama hal tersebut rasional. Jadi penentu

${ }^{22}$ Leonora Tubbs Tisdale, Preaching as Local Theology and Folk Art (Minneapolis, MN: Fortress Press, 1997), 32-33.

${ }^{23}$ Stanly J. Grenz, A Primer on Postmodernism (Grand Rapids, MI: William B. Eermans Publishing Company, 1996), 2.

${ }^{24}$ Willy Gaut, Filsafat Postmodernisme Jean-François Lyotard: Tesis-Tesis Kunci dan Masalah Status Pengetahuan Ilmiah (Flores: Penerbit Ledalero, 2011), 30. 
kebenaran adalah akal manusia yang dapat berpikir kritis dalam mencari bukti empiris dalam penentuan sebuah kebenaran. Hanya saja, pendekatan rasio dalam pencarian kebenaran tidak memberikan kepuasan karena era modern hanya menekankan satu sisi dari aspek manusia itu sendiri, yakni aspek rasio manusia dan mengabaikan aspek rasa atau intuisi. Ketidakpuasan tersebut menyebabkan lahirnya era yang baru.

Postmodern merupakan era yang muncul karena ketidakpuasan terhadap era modern yang cenderung anthropocentric. Istilah postmodern mengarah pada suatu pergeseran budaya, serta mencoba menjelaskan akar-akar filosofis di belakang pikiran-pikiran yang menganalisa realitas masyarakat masa kini. ${ }^{25}$ Pandangan dunia postmodern lebih menekankan pada keberadaan (realitas) yakni hal yang berkaitan langsung dengan pengalaman dari pada hal mengetahui (ide) atau hal-hal yang bersifat konseptual ${ }^{26}$ dan abstrak. Dengan kata lain, pandangan dunia postmodern merupakan sebuah perubahan pola pikir yang merupakan akibat dari ketidakpuasan terhadap modernism. Karena itu, pandangan dunia postmodern memiliki karakteristik yang perlu untuk diketahui sebagai usaha dalam memahami trend pola pikir masyarakat postmodern.

Pertama, kebenaran yang bersifat relatif. Menurut postmodernisme, tidak ada satu hal pun yang kita pikir kita ketahui yang bisa diuji dengan realitas itu sendiri. ${ }^{27}$ Dengan kata lain, apa yang mereka ketahui dan mereka alami barulah menjadi sebuah kebenaran. Tolak ukur kebenaran dapat diperoleh dari kesepakatan lingkungan yang sama-sama mengalami apa yang mereka ketahui. Sire menambahkan bahwa kebenaran adalah apa yang bisa disepakati oleh rekan-rekan kita (komunitas). ${ }^{28}$

Tidak ada kebenaran yang absolut yang menjadi tolak ukur kebenaran dalam pandangan dunia postmodern sebab manusialah yang menjadi penentu kebenaran berdasarkan realitas pengalaman mereka. Erickson menjelaskan bahwa pandangan postmodernism yang berkaitan dengan kebenaran selalu bervariasi dan tidak ada kesamaan. Dengan kata lain, pemahaman kebenaran mengalami perbedaan di setiap kebudayaan. ${ }^{29}$ Perbedaan ini dikarenakan manusia yang menjadi tolak ukur kebenaran sehingga kebenaran dalam pandangan dunia postmodern bersifat subjektive dan relative. Hal ini berbeda dengan pandangan dunia Kristen yang menekankan kebenaran yang objektif serta yang menjadi tolak

${ }^{25}$ H. W. B. Sumakul, Postmodernitas: Memaknai Masyarakat Plural Abad Ke-20 (Jakarta, IDN: BPK Gunung Mulia, 2012), 10.

${ }^{26}$ James W. Sire, The Universe Next Door: A Basic World View Catalog (Surabaya, IND: Momentum, 2005), 233.

${ }^{27}$ Ibid., 240.

${ }^{28}$ Ibid., 241.

${ }^{29}$ Milllard J. Erickson, The Postmodern World: Discerning the Times and the Spirit of Our Age (Wheaton, IL: Crossway Books a Division of Good News Publisher, 2002), 66. 
ukur kebenaran adalah Alkitab. Pergeseran pemahaman mengenai kebenaran dalam masyarakat postmodern menjadi tantangan tersendiri bagi para pengkhotbah Kristen.

Karakteristik yang kedua dari spiritualitas postmodernisme adalah positivisme. Positivisme merupakan suatu praktik keyakinan yang berlebihan. Istilah lain yang cocok dengan positivisme adalah fideism. Fideism merupakan sebuah paham yang menekankan keyakinan yang bersifat positif terhadap sesuatu yang sadari dapat memberikan sebuah keadaan yang baik. Greer mengatakan bahwa secara teknis, fideism berarti faith in faith (iman di dalam iman). Hal tersebut adalah sebuah keyakinan/iman yang tidak memiliki referensireferensi eksternal di luar dirinya sendiri yang berarti untuk mensyahkan atau memalsukan yang mana seorang percaya menegaskan untuk menjadi benar. ${ }^{30}$

Johnston menjelaskan, "Today postmodernity says, All you can believe is what's in your own heart, count on intuition and faith, give up on the idea of truth, have an experienced instead." ${ }^{31}$ Karakteristik masyarakat postmodern terlihat pada penekanan terhadap keyakinan terhadap yang ada dalam hati mereka dan membawanya pada dimensi pengalaman. Keyakinan ini merupakan tindakan berpikir positif yang mengarah kepada sesuatu yang diyakini untuk memperoleh atau mendapatkan kebenaran. Greer menambahkan bahwa fideism adalah sebuah konsep yang memiliki keyakinan pada diri sendiri, mengandaskan sistem faith in faith. Hal tersebut kerapkali dihubungkan dengan iman yang dikarakterisasi dengan kenaifan, kesederhanaan berpikir dan pemikiran yang penuh harapan. ${ }^{32}$

Ketiga, menekankan unsur pengalaman. Meminjam istilah yang diungkapkan oleh Joe Holland "spiritualitas postmodern bisa diungkapkan sebagai sesuatu yang berwujud. Hal ini bertentangan gagasan klasik tentang transendensi yang tidak berwujud." ${ }^{33}$ Dengan kata lain, postmodern lebih menekankan aspek imanensi dari pada aspek transendensi. Tubuh, masyarakat, dan alam merupakan mediator-mediator utama antara sang Ilahi dan manusia. ${ }^{34}$

Karakteristik pandangan dunia postmodern yang keempat adalah penekanan pada hubungan atau jejaring. Jika teknologi ${ }^{35}$ tepat guna dan koperasi komuniter merupakan pelopor prinsip ekonomi dalam masyarakat postmodern, maka prinsip politik adalah

${ }^{30}$ Robert C. Greer, Mapping Postmodernism: A Survey of Christian Option (Doweners Grove, Il: InterVarsity Press, 2003), 236.

${ }^{31}$ Graham Johnston, Preaching to the Postmodern World: A Guide to Reaching Twenty-First Century Listeners, second. (Grand Rapids, MI: Baker Books, 2002), 9.

${ }^{32}$ Greer, Mapping Postmodernism, 237

${ }^{33}$ Joe Holland, Visi Postmodern Tentang Spiritualitas Dan Masyarakat, ed. David Ray Griffin (Yogyakarta, IDN: Penerbit Kanisius, 2005), 76.

34 Ibid., 76.

${ }^{35}$ Veith, Guide to Contemporary Culture, 177. Era computer merupakan symbol dari ekonomi postmodern yang biasa dikenal sebagai era digital. Sekarang ini, sistem komputerisasi telah mengambil alih operasi-operasi di perusahan-perusahan. Manusia tinggal duduk di depan computer dan mengakses informasiinformasi yang ada. Pabrik-pabrik era modern mengizinkan perusahaan-perusahan untuk menghasilkan kelompok-kelompok khusus dalam bermitra melalui jejaring sosial internet 
pembelaan atau pembangunan kembali komunitas yang berakar dan penyebaran jaringan solidaritas internasional pada komunitas-komunitas yang berakar. ${ }^{36}$ Hubungan dapat menciptakan komunitas dan hubungan merupakan pengikat dalam terwujudnya sebuah organisme.

Budaya postmodern melahirkan suatu generasi yang baru dan mewarnai pandangan budaya tersebut dalam perilaku-perilaku sosial mereka. Generasi milenial merupakan generasi yang lahir dalam era postmodern sehingga memiliki budaya yang unik dalam mewarnai perilaku sosial masyarakat postmodern. Generasi milenial memiliki cara yang unik dalam memperoleh kebenaran dan kebenaran yang diyakininya menjadi sebuah budaya yang membentuk identitas mereka dalam bersosial di tengah masyarakat. Perilaku sosial generasi ini tentu tidak lepas dari pengaruh perkembangan teknologi informasi yang membentuk pemikiran dan perilaku mereka.

\section{Generasi Milenial}

Era ini disebut sebagai era komputer yang menjadi simbol ekonomi postmodern yang biasa dikenal sebagai era digital. ${ }^{37}$ Saat ini, sistem komputer telah mendominasi semua operasional perusahan-perusahan di mana para pekerja duduk di depan computer dan melakukan segala pekerjaannya serta mengakses informasi-informasi yang ada. Generasi milenial lahir dan bertumbuh dalam dunia era internet yang mana generasi ini sangat akrab dengan koneksi internet. Koneksi internet sangat penting bagi generasi milenial karena dapat membantu mereka dalam mencari informasi-informasi yang mereka ingin ketahui bahkan terkait pekerjaan mereka. Karena itu, jejaring sosial internet sangat diperlukan bagi generasi milenial untuk mengakses pekerjaan-pekerjaan mereka serta penemuan-penemuan informasi yang mereka perlukan.

Siapakah yang termasuk dalam kategori generasi milenial? Pertanyaan ini menolong untuk dapat melakukan klasifikasi terhadap usia kelahiran kelompok generasi milenial. Generasi awal milenial lahir pada sekitar awal tahun 1980-an. Sebagaimana riset terkait awal kelahiran generasi milenial yang dilakukan oleh Lembaga penelitian Pew research Center menyatakan bahwa "The label refers those born after 1980 - the first generation to come of age in the new millennium." 38 Generasi milenial memasuki era yang baru yang disebut

\footnotetext{
${ }^{36}$ Holland, Visi Postmodern, 86. Penggunaan istilah "politik" oleh Holland bukan dalam pengertian yang sempit sebagai negara dan partai modern, melainkan dalam pengertian yang lebih luas sebagai bentuk organisasi suatu masyarakat.

${ }^{37}$ Gene Edward Veith, Guide to Contemporary Culture (Leicester: Crossway Books, 1994), 177.

38 "Millennials: Confident, Connected, Open to Change," Pew Research Center, 4. Accessed July 13, 2019, https://www.pewresearch.org/wp-content/uploads/sites/3/2010/10/millennials-confident-connected-opento-change.pdf.
} 
sebagai generasi era digital di mana perkembangan informasi dan teknologi begitu masif dan cepat. Itulah sebabnya, generasi ini umumnya disebut sebagai generasi teknologi. Kebanyakan generasi milenial paham teknologi bahkan mereka lebih paham dari orang tua mereka. Generasi ini bisa belajar lebih cepat melalui teknologi informasi yang mereka miliki.

Generasi milenial merupakan generasi yang perlu dipertimbangkan untuk dijadikan fokus pembahasan dalam pendidikan Kristen di dalam gereja. Generasi ini tidak bisa diabaikan sebab generasi ini merupakan generasi yang sedang menyaksikan dan juga merupakan pelaku dari perubahan budaya yang terjadi saat ini. Gereja tidak bisa mengabaikan begitu saja kelompok generasi milenial dan perlu memberi ruang untuk mendengarkan apa yang menjadi kebutuhan mereka bahkan termasuk kebutuhan mereka dalam mencari kebenaran. Gereja perlu melakukan strategi khusus bagaimana menjangkau mereka dengan cara mempelajari serta berusaha memahami karakteristik generasi milenial.

Ketika gereja berusaha untuk memahami kelompok generasi milenial, maka gereja sedang berusaha secara efektif dalam menjangkau serta memuridkan mereka. Sebagaimana amanat agung Yesus dalam Matius 28:19-20, Perintah Yesus melalui amanat agung-Nya bukan hanya sebatas perintah lintas ras, suku, dan bangsa, namun juga memiliki implikasi lintas generasi. Karena itu, gereja memiliki peran penting dalam menyampaikan khotbah kepada generasi milenial yang merupakan bagian dari gereja itu sendiri yang sedang bertumbuh.

Gereja perlu memikirkan bagaimana seharusnya menjangkau generasi milenial secara efektif agar mereka dapat dimuridkan dengan baik. Lembaga survei Aspen Group menunjukkan bahwa, "In light of these shifting assumptions, churches need to respond to the needs and expectations of Milenials." 39 Salah satu strategi yang perlu dipikirkan dalam menjangkau generasi milenial adalah dalam kaitannya dengan pemberitaan khotbah yang efektif kepada generasi ini. Strategi tersebut merupakan usaha untuk memberikan respon terhadap apa yang menjadi kebutuhan serta harapan-harapan generasi milenial. Strategi pemberitaan Firman melalui khotbah kepada gerenasi milenial merupakan sarana pemberian makanan rohani kepada mereka agar mereka dapat bertumbuh secara efektif dalam pengetahuan maupun pengenalan akan kebenaran Firman Tuhan yang membantu mereka untuk mengalami perubahan hidup ke arah yang lebih baik. Perubahan hidup untuk menjadi lebih baik bergantung bagaimana mereka berdialog dengan kebenaran Firman melalui khotbah yang mereka dengarkan dalam setiap ibadah yang mereka hadiri.

Sebagaimana yang Yesus sampaikan dalam amanat agung-Nya kepada gereja bahwa Ia

${ }^{39}$ Aspen Group, "Making Space for Millennials," Cornerstone Knowledge Network/Barna Group Research Project, 9. last modified 2004, http://jtai.net/JTAI/wpcontent/uploads/2018/10/MSFM_Ex_Summary_final.pdf. 
akan menyertai gereja-Nya sampai kepada akhir zaman (Mat. 19:20), maka Yesus akan terus menerus memberdayakan gereja-Nya untuk lebih efektif dalam memberitakan kebenaran Firman dalam setiap perubahan zaman yang terjadi. Karena itu, gereja ditantang untuk terlibat aktif dalam mempelajari karakteristik dari orang-orang atau generasi-generasi tertentu yang menjadi pelaku dalam perubahan budaya, persepsi, maupun asumsi-asumsi pemikiran yang ada. Terkait generasi milenial, gereja memiliki tugas dan tanggung jawab yang besar untuk memahami karakteristik generasi ini sehingga dapat menyampaikan berita Firman melalui khotbah dengan efektif.

\section{Karakteristik Generasi Milenial}

Generasi milenial merupakan generasi baru yang diperkirakan lahir mulai awal tahun 1982. Rickes mengungkapkan bahwa generasi milenial merupakan generasi yang baru dan memiliki aturan pengalaman hidup yang berbeda. Itulah sebabnya, Rickes menegaskan bahwa,

Milenials are motivated and achievement-oriented team players who respect authority and are concerned with social justice. They are also realists, blending the staid loyalty of Silent with the unbridled optimism of Boomers, while adding a healthy dose of skepticism from Gen Xers. ${ }^{40}$

Kelompok milenial menunjukkan diri sebagai generasi yang unik di mana generasi ini memiliki aturan hidup yang berbeda dengan generasi-generasi sebelumnya. Kelompok generasi pertama, G.I. Generation atau biasa disebut sebagai Great Generation. Generasi ini lahir antara 1901-1924 sehingga biasanya generasi ini dipanggil sebagai civic generation. Generasi GI adalah generasi yang memiliki komitmen terhadap identitas kewarganegaraan mereka karena dilatarbelakangi oleh keadaan perang dunia II. ${ }^{41}$ Generasi GI memiliki orientasi kepada tim. ${ }^{42}$ Kedua, Silent Generation. Silent Generation lahir sekitar 1925-1942 dan merupakan generasi yang berorientasi kepada keluarga dan teman. ${ }^{43}$ Ketiga, The Boomer Generation yang lahir sekitar 1943-1960 dan merupakan generasi yang idealis. ${ }^{44}$ Keempat, Generasi X (lahir sekitar 1961-1981) yang memiliki sikap reaktif atas ketidakpuasan terhadap generasi orang tua mereka yang cenderung memiliki sikap yang mengendalikan mereka. Generasi X tidak senang ketika mereka mulai dikontrol oleh orang tua mereka. ${ }^{45}$ Kelima, generasi milenial lahir sekitar tahun 1982-2001. Generasi milenial memiliki keunikan yang

\footnotetext{
${ }^{40}$ Persis C. Rickes, “Make Way for Millennials! How Today's Students Are Shaping Higher Education Space," The Journal of the Society for College and University Planning 37, no. January-March (2009), 10 https://rickesassociates.com/wp-content/uploads/2017/05/6_Make-Way-for-Millennials.pdf.

${ }^{41}$ Rose M. Kundanis, Children, Teens, Families, and Mass Media : The Millennial Generation (Mahwah, NJ: Lawrence Erlbaum Associates, 2003), 35.

${ }^{42}$ Rickes, "Make Way for Millennials!, 8"

${ }^{43}$ Ibid., 8.

${ }^{44}$ Kundanis, Children, Teens, Families, and Mass Media, 37.

45 Ibid., 39.
} 
perlu diketahui sehingga dapat menolong bagaimana menjangkau mereka dengan pendekatanpendekatan yang cocok dengan karakteristik generasi tersebut.

\section{Optimistik}

Salah satu keunikan generasi milenial yang menjadi ciri khasnya adalah penekanan terhadap sikap optimis. Generasi milenial merupakan produk dari postmodern yang membangun spiritualitas positive thinking. Itulah sebabnya, generasi milenial kerap menekankan aspek berpikir positif dalam memperoleh atau mencapai suatu tujuan. Dalam sebuah survei menemukan bahwa "Millennials have been found to be optimistic about their own futures and about the world that today's youth will inherit."46

Pernyataan tersebut didukung oleh lembaga survei Pew Research Center yang menunjukkan bahwa generasi milenial lebih menunjukkan sikap yang optimis daripada generasi orang tua mereka. Hasil survei tersebut mengatakan,

However, young workers are more optimistic than older workers about their future earning power. Among Millennials who say they don't earn enough money, 88\% think they will be able to earn enough in the future. This compares with $76 \%$ of Gen Xers and $46 \%$ of Boomers. These measures have changed very little since 2006 , when $32 \%$ of those under age 30 who were employed either full time or part time said they made enough money to live the kind of life they wanted. Among those who didn't earn enough, 92\% said they thought they would in the future. Today's employed young people are actually somewhat more optimistic about their economic future than Gen Xers were when they were young. ${ }^{47}$

Hasil temuan lembaga survei di atas menunjukkan bahwa generasi milenial memiliki pandangan yang lebih optimis terhadap masa depan dari pada generasi orang tua mereka, yakni generasi X, pada masa muda mereka. Erick Greenberg dan Karl Weber menjelaskan bahwa generasi milenial merupakan generasi spesial yang tidak pessimistic. Mereka memiliki keyakinan terhadap perkembangan teknologi dan memahami bagaimana mengembangkannya dan melakukan suatu inovasi. Hal yang paling penting bagi generasi milenial menurut Greenberg dan Weber, "they believe in the greater good and are ready to dedicate themselves to achieving it." ${ }^{48}$

Sikap positif dalam menghadapi masa depan menegaskan bahwa generasi milenial merupakan generasi yang sangat optimistik. Oleh karena itu, generasi tersebut perlu diberikan kata-kata yang memberi dorongan serta menunjukkan model gaya hidup yang memberi

${ }^{46}$ Leesa Tanner, Who Are the Millennials? (Canada, n.d.), 32. http://cradpdf.drdcrddc.gc.ca/PDFS/unc104/p534334_A1b.pdf.

${ }^{47}$ Kohut, et all, "Millennials," 20.

${ }^{48}$ Eric H Greenberg and Karl Weber, Generation We: How Millennial Youth Are Taking Over America and Changing Our World Forever (Emeryville, CA: Pachatusan, 2008), 6.

155 | Copyright@ 2021, CARAKA, ISSN 2722-1407 (Cetak), 2722-1393 (Online) 
inspirasi kepada mereka untuk mencapai suatu tujuan yang yang ingin dicapai dan menjadikan keadaan lebih baik dari yang sebelumnya.

\section{Antusias}

Selain dikenal sebagai generasi yang optimis, generasi milenial merupakan generasi yang memiliki ciri semangat yang tinggi dalam mencapai suatu tujuan. Dengan kata lain, generasi milenial adalah generasi yang penuh antusias dalam mempelajari sesuatu sehingga impian-impian yang ingin dicapai dapat terwujud. Sebagai generasi yang memiliki impian yang tinggi, maka generasi milenial dikenal sebagai generasi yang suka mengajukan pertanyaan terhadap sesuatu seperti misalnya, "mengapa sesuatu bisa terjadi?" Mereka lebih suka menanyakan secara langsung bagaimana sesuatu hal bisa bekerja daripada membuang waktu untuk mencoba membayangkannya dengan imajinasi mereka. ${ }^{49}$ Tujuan mereka mengajukan pertanyaan adalah agar mereka memiliki gambaran dari apa yang akan mereka ingin capai atau raih. Sikap ini perlu diberikan ruang untuk mengapresiasi mereka karena dengan gigih atau penuh antusias telah membuka diri mereka untuk mengetahui dari sesuatu yang ingin dicapai.

Sifat penuh antusias dalam mempelajari sesuatu yang membuat generasi milenial tidak suka membuang waktu mereka. Mereka lebih suka mengajukan pertanyaan secara langsung supaya dapat mempelajarinya dengan cepat. Keinginan dalam mempelajari sesuatu hal, menjadikan generasi ini sebagai generasi instan yang tidak terlalu suka membuang waktu mereka belajar terlalu lama.

\section{Multi-Tasking}

Perkembangan teknologi yang begitu masif pada saat ini menuntut generasi milenial menjadi multi-taskers yang ahli. Sebagai generasi yang bertumbuh dalam perkembangan teknologi membuat generasi ini dapat mengerjakan beberapa pekerjaan dalam waktu yang bersamaan. Tunner mengatakan, "Millennials can IM (instant message) while doing homework, text while at the movies, listen to their iPod while on the computer, and chat with Facebook friends while watching television."50 Tanner telah memberikan gambaran jelas mengenai perilaku sosial generasi milenial dalam sebuah pertemuan. Generasi milenial kerap melakukan berbagai pekerjaan seperti mengirim pesan, mendengarkan musik pada waktu yang bersamaan ketika sedang mengerjakan tugas-tugas lainnya. Tidak menutup kemungkinan bahwa generasi milenial yang hadir dalam ibadah bisa melakukan pekerjaan melalui ponsel pintar mereka sementara mendengarkan khotbah. Hal ini bisa menjadi tantangan bagi

${ }^{49}$ Tanner, Who Are the Millennials?, 34.

${ }^{50}$ Ibid., 35 
pengkhotbah ketika berdiri di hadapan generasi ini di mana pemandangan yang tidak diharapkan terjadi. Pengkhotbah mengharapkan pendengarnya memberi perhatian atas atas berita khotbahnya, namun pada saat yang sama generasi ini bisa melakukan pekerjaan lain sementara khotbah diberitakan.

\section{Bahasa Gaul}

Bahasa generasi milenial sangat dipengaruhi oleh budaya populer yang berkembang saat ini. ${ }^{51}$ Bahasa merupakan bagian terpenting dalam sebuah komunikasi guna mempererat relasi. Setiap generasi memiliki gaya bahasa yang diungkapkan agar maksudnya dapat dipahami oleh pendengarnya yang diajak untuk berkomunikasi. Generasi milenial memiliki gaya tersendiri dalam berkomunikasi yang mana kerap disebut sebagai bahasa gaul. Bahasa gaul adalah bahasa popular yang dikenal oleh orang-orang muda atau para generasi milenial.

Generasi milenial mengalami pergeseran bahasa yang kerap seperti bertentangan dengan bahasa baku. Pergeseran ini tidak lepas dari perkembangan teknologi informasi sehingga mempengaruhi pola komunikasi generasi milenial dalam penggunaan slang atau bahasa gaul. Dalam pengamatan media massa, "Kaum milenial cenderung lebih suka bahasa gaul dari pada bahasa Indonesia yang baik dan benar." 52 Idi Subandi Ibahim menjelaskan bahwa bahasa merupakan sarana untuk mengkomunikasikan identitas suatu komunitas. ${ }^{53}$

Berkhotbah merupakan sarana untuk mengomunikasikan kebenaran Firman Allah kepada komunitas orang percaya. Penyampaian khotbah melibatkan keaktifan pengkhotbah dalam memilih kata yang tepat untuk para pendengar. Tantangan pengkhotbah dalam menyampaikan khotbah adalah bagaimana mempersiapkan khotbahnya melalui proses mengeksegesa teks yang hendak dikhotbahkan dan pada saat yang sama mengeksegesa pendengar. Proses eksegesa pendengar adalah sikap dimana seorang pengkhotbah menaruh perhatian kepada pendengarnya. Ketika berkhotbah kepada generasi milenial, pengkhotbah juga harus memperhatikan bahasa yang yang popular di kalangan mereka agar mereka dapat memberikan perhatian, menolong mereka untuk memahami apa yang dikhotbahkan serta dapat meyakinkan mereka. Pengkhotbah perlu mempelajari kultur bahasa gaul generasi milenial agar khotbah mereka tidak terkesan membosankan.

Mempelajari karakteristik pendengar adalah usaha dalam mendengarkan kebutuhan pendengar dari isi khotbah yang akan disampaikan. Schraf mengatakan, "kita menunjukkan

${ }^{51}$ John Fiske, Memahami Budaya Populer (Yogyakarta: Jalasutra, 2017), 121.

52 Tomi Dwiki Nugraha, "Pergeseran Tata Bahasa Indonesia di Kalangan Milenial," Kompasiana, accessed February 27, 2020, https://www.kompasiana.com/tomidwikinugraha7577/5c605525677ffb3d4028bd54/pergeseran-tata-bahasaindonesia-di-kalangan-generasi-milenial?page=all\#sectionall.

${ }^{53}$ Idi Subandy Ibrahim, Budaya Populer Sebagai Komunikasi (Yogyakarta: Jalasutra, 2007), 121. 157 | Copyright $\odot$ 2021, CARAKA, ISSN 2722-1407 (Cetak), 2722-1393 (Online) 
hormat kepada pendengar kita dengan mendengarkan mereka."54 Mempelajari karakteristik pendengar merupakan sikap hormat dari pengkhotbah dan tentu sikap ini harus dipertahankan agar pendengar juga merasa ada kasih yang nampak dalam diri pengkhotbah sendiri. Di sinilah letak ketulusan kasih pengkhotbah dalam menyampaikan firman Tuhan, yakni memberi hormat kepada mereka melalui mempelajari karakteristik pendengarnya. Itulah sebabnya Schraf lebih lanjut mengungkapkan bahwa menunjukkan sikap hormat kepada pendengar merupakan upaya untuk memahami mereka dengan kesungguhan hati. Schraf memberikan empat usaha dalam memahami pendengar. Pertama, belajar memahami manusia secara umum dalam perspektif Alkitab. Kedua, menempatkan diri pada posisi pendengar. Ketiga, mendengarkan secara bijak dan kritis informasi pengetahuan dari orang lain. Keempat, belajar secara langsung dari pendengar itu sendiri. ${ }^{55}$ Usaha mendengarkan pendengar akan menolong pengkhotbah untuk belajar mengetahui apa yang menjadi kebutuhan mereka atau sebaliknya mereka sedang memberitahukan pergumulan kerohanian mereka agar mereka dikuatkan kembali dengan berita firman yang hendak disampaikan.

\section{KESIMPULAN}

Pengkhotbah harus mampu menyampaikan isi khotbah dalam lintas generasi dengan model pendekatan melalui memahami pendengarnya. Sebagai contoh, bagaimana menyampaikan khotbah yang efektif kepada generasi milenial. Penyampaian khotbah dalam lintas generasi menolong pengkhotbah untuk berkhotbah secara kreatif tanpa mengubah makna utama dari pesan teks Kitab Suci yang disampaikan.

Terkait strategi berkhotbah yang efektif kepada generasi milenial, seorang pengkhotbah mengemasi isi khotbah yang yang alkitabiah dengan memilih diksi-diksi yang populer di kalangan mereka. Pemilihan diksi 'gaul' yang memiliki nuansa memberikan dorongan positif dalam berkhotbah. Hal ini tentunya sangat mempengaruhi pendengar milenial untuk antusias mendengarkan isi khotbah. Selanjutnya, durasi khotbah tidak boleh terlalu lama dan bertele-tele sebab generasi milenial adalah generasi yang to the point yang langsung menyentuh inti sehingga khotbah dapat dipahami dan diterima dengan baik.

\footnotetext{
${ }^{54}$ Greg Schraf, Khotbah Yang Transformatif: Memperdalam Hubungan Dengan Allah, Firman Allah, dan Para Pendegar (Jakarta: Yayasan Komunikasi Bina Kasih, 2013), 266.

55 Ibid., 367. 


\section{DAFTAR PUSTAKA}

Buttrick, David G. Homeiletic: Moves and Structures. Philadelphia: Fortress Press, 1987. Erickson, Milllard J. The Postmodern World: Discerning the Times and the Spirit of Our Age. Wheaton, IL: Crossway Books a Division of Good News Publisher, 2002.

Fiske, John. Memahami Budaya Populer. Yogyakarta: Jalasutra, 2017.

Gaut, Willy. Filsafat Postmodernisme Jean-François Lyotard: Tesis-Tesis Kunci Dan Masalah Status Pengetahuan Ilmiah. Flores: Penerbit Ledalero, 2011.

Gibson, Scott M. "Introduction." In Preaching to a Shifting Culture: 12 Perspective on Communicating That Connects, edited by Scott M Gibson. Grand Rapids, MI, 2004.

Gonzalez, Justo L. The Story of Christianity: The Reformation to the Present Day. New York, NY: Harper Collins Publishers, 2010.

Green, Chris E. W. "Transfiguring Preaching: Salvation, Mediation, and Proclamation." In Toward a Pentecostal Theology of Preaching, edited by Lee Roy Martin. Cleveland, TN: CPT Press, 2015.

Greenberg, Eric H, and Karl Weber. Generation We: How Milenial Youth Are Taking Over America and Changing Our World Forever. Emeryville, CA: Pachatusan, 2008.

Greer, Robert C. Mapping Postmodernism: A Survey of Christian Option. Doweners Grove, Il: InterVarsity Press, 2003.

Grenz, Stanly J. A Primer on Postmodernism. Grand Rapids, MI: William B. Eermans Publishing Company, 1996.

Group, Aspen. "Making Space for Milenials." Cornerstone Knowledge Network/Barna Group Research Project. Last modified 2004. http://jtai.net/JTAI/wpcontent/uploads/2018/10/MSFM_Ex_Summary_final.pdf.

Holland, Joe. Visi Postmodern Tentang Spiritualitas dan Masyarakat. Edited by David Ray Griffin. Yogyakarta, IDN: Penerbit Kanisius, 2005.

Ibrahim, Idi Subandy. Budaya Popiler Sebagai Komunikasi. Yogyakarta: Jalasutra, 2007. Johnston, Graham. Preaching to the Postmodern World: A Guide to Reaching Twenty-First Century Listeners. Second. Grand Rapids, MI: Baker Books, 2002.

Kohut, Andrew. "Milenials: Confident, Connected, Open to Change." Pew Research Center. Last modified 2010. Accessed July 13, 2019. https://www.pewresearch.org/wpcontent/uploads/sites/3/2010/10/milenials-confident-connected-open-to-change.pdf.

Kundanis, Rose M. Children, Teens, Families, and Mass Media : The Milenial Generation. Mahwah, NJ: Lawrence Erlbaum Associates, 2003.

Nugraha, Tomi Dwiki. "Pergeseran Tata Bahasa Indonesia Di Kalangan Milenial." Kompasiana. Accessed February 27, 2020.

https://www.kompasiana.com/tomidwikinugraha7577/5c605525677ffb3d4028bd54/perge seran-tata-bahasa-indonesia-di-kalangan-generasi-milenial?page=all\#sectionall.

Rickes, Persis C. "Make Way for Milenials! How Today's Students Are Shaping Higher Education Space." The Journal of the Society for College and University Planning 37, no. January-March (2009). https://rickesassociates.com/wpcontent/uploads/2017/05/6_Make-Way-for-Milenials.pdf.

Schraf, Greg. Khotbah Yang Transformatif: Memperdalam Hubungan Dengan Allah, Firman Allah, Dan Para Pendegar. Jakarta: Yayasan Komunikasi Bina Kasih, 2013.

Sire, James W. The Universe Next Door: A Basic World View Catalog. Surabaya, IND: Momentum, 2005.

Sumakul, H. W. B. Postmodernitas: Memaknai Masyarakat Plural Abad Ke-20. Jakarta, IDN: BPK Gunung Mulia, 2012.

Tanner, Leesa. Who Are the Milenials? Canada, n.d. http://cradpdf.drdcrddc.gc.ca/PDFS/unc104/p534334_A1b.pdf.

Tennent, Timothy C. "Evangelical Preaching in the Global Context." In Preaching to a Shifting Culture: 12 Perspective on Communicating That Connects, edited by Scott M. Gibson. Grand Rapids, MI, 2004. 
CARAKA: Jurnal Teologi Biblika dan Praktika, Vol. 2, No. 2, November 2021

Tisdale, Leonora Tubbs. Preaching as Local Theology and Folk Art. Minneapolis, MN: Fortress Press, 1997.

Veith, Gene Edward. Guide to Contemporary Culture. Leicester: Crossway Books, 1994.

Vines, Jerry, and Jim Shaddix. Homeletika: Kuasa Dalam Berkhotbah. Malang, IDN: Gandum Mas, 1999.

Wiersbe, Warren W. The Dynamics of Preaching. Grand Rapids, MI: Baker Publishing Group, 1999. 